
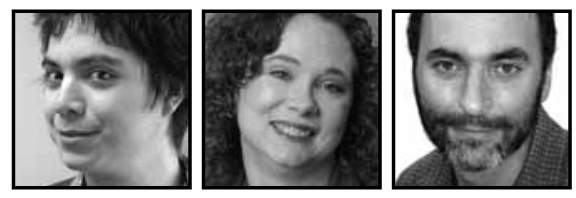

\title{
Transforming Teaching and Learning Through Critical Media Literacy Pedagogy
}

\author{
Antero Garcia, Colorado State University \\ Robyn Seglem, Illinois State University \\ Jeff Share, University of California, Los Angeles
}

\section{ABSTRACT}

This article provides a framework and examples for critical media literacy pedagogy. More than simply guiding how students read and interpret the texts they encounter, critical media literacy pedagogy pushes to illuminate the underlying power structures that are a part of every media text. Throughout this article, examples from working with high school youth and preservice teachers are provided. In recognizing recent shifts in media production as a result of participatory culture, this article focuses on how youth-created media products are an integral part of a 21st century critical media literacy pedagogy.

\section{Introduction}

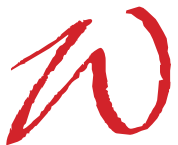

orking with partners, students in a senior advanced placement (AP) English class work to apply the concepts they have been studying in Jackson and Jamieson's (2007) book, unSpun: Finding facts in a world of disinformation, a book that aims to educate readers about how to sift through the reams of information that bombard them on a daily basis and identify spin, half-truths, and outright lies. Their teacher has assigned each pair a different chapter of the book. The pairs seek out examples that will synthesize the ideas in their assigned chapters with examples from around the world and compose a presentation using prezi.com that will share their findings with the class. They take advantage of multiple media, 
including newspaper clippings that detail medical fraud, advertisements that hype alcohol, and videos that focus on the effects of war. All of these things, the students contend, speak to the misinformation saturating the world.

In designing this assignment, the teacher sought to expose her students to rhetorical elements, such as euphemism or hyperbole, used to manipulate belief systems and to encourage her students to begin to critically analyze text. By pushing her students to look beyond printed pages, one might even say she is engaging them in media literacy. Indeed, the National Association for Media Literacy Education defines media literacy as the ability to "access, analyze, evaluate, and communicate information in a variety of forms, including print and non-print messages," (Media literacy defined, 2013) and the students in this classroom demonstrated these skills by accessing images from the media to illustrate the ideas represented in the chapter, analyzing the messages of each example through the critical lens of their assigned chapter, evaluating the merit of the message for each example, and communicating their findings through the media tool Prezi. The value of this assignment cannot be disputed. Students walked away with a deeper understanding of how language and other symbols can be used to manipulate people's understanding of the world. We contend, however, that teachers cannot stop with assignments such as these. Rather, students need to be empowered to produce media messages that move beyond sharing their understanding of a unit of study to creating multimedia texts designed to challenge the thinking of the world around them. By approaching instruction with this goal in mind, teachers can begin to engage in critical media literacy pedagogy.

\section{The Origins of Critical Media Literacy}

Critical media literacy has evolved from many disciplines, yet the principal arena of theoretical work comes from the multidisciplinary field of cultural studies. Over a century ago in Europe, theorists began seriously critiquing media and society. From the 1930s through the 1960s, researchers at the Frankfurt Institute for Social Research used critical social theory to analyze the ways popular culture and the new tools of communication technology encourage ideology and social control (Adorno \& Horkheimer, 1944). In the 1960s, researchers at the Centre for Contemporary Cultural Studies at the University of Birmingham added to the earlier interests in ideology with a more sophisticated understanding of the audience as active makers of meaning, not simply mirrors of an external reality (Durham \& Kellner, 2005). Using the lenses of semiotics, multiculturalism, feminism, and postmodernism, critical media 
literacy theorists developed a dialectical understanding of textual analysis, political economy, and audience theory that allows popular culture and media to be analyzed as dynamic forces that often reproduce dominant ideologies. This approach also opens up possibilities for counter-hegemonic alternatives (Kellner, 1995). In the 1980s, cultural studies research began to enter the educational arena. With the publication of Len Masterman's Teaching the Media (2001), many educators around the world embraced media education less as a specific body of knowledge or set of skills and more as a framework of conceptual understandings (Buckingham, 2003).

Various people and organizations across the globe have generated different lists of media literacy concepts that vary in numbers and wording, but for the most part they tend to coincide with at least five basic elements: 1) recognition of the construction of media as a social process; 2 ) hermeneutical analysis that explores the languages, genres, codes, and conventions of any text; 3 ) exploration of the audience's role in negotiating meanings; 4) problematizing the process of representation to unveil and engage issues of power, ideology, and pleasure; 5) examination of the institutions and political economy that structure media industries as profit-seeking businesses (Kellner \& Share, 2007; Masterman, 2001; Thoman \& Jolls, 2005).

Critical media literacy as we are defining it here is a progressive educational response that expands the notion of literacy to include different forms of mass communication, popular culture, and new technologies and also deepens literacy education to critically analyze relationships between media and audiences, information, and power. Along with this analysis, alternative media production is an essential component of critical media literacy as it empowers students to create their own messages that can challenge media texts and narratives. While some popular approaches to media literacy distance themselves from critical literacy and critical pedagogy (Scheibe \& Rogow, 2012; Hobbs, 2011; Buckingham, 2003), we believe that critical media literacy depends on guiding students to explore difficult-to-see ideologies and connections between power and information. This approach embraces a democratic pedagogy, in which teachers and students study multiple narratives and ideological power structures as they push back on the popular myth that education can and should be apolitical. Like the title of Howard Zinn's book (2002) and documentary (2004), "you can't be neutral on a moving train," social justice educators like Zinn recognize the fact that education is by its very nature a political act (Giroux, 2001). In light of the current movement for standardization, high-stakes testing, and scripted curriculum, it is now more important than ever for all educators to recognize the conservative nature of education and commercial media, and challenge their role in replicating dominant ideologies and oppressive social structures. 
Using critical media literacy, social justice educators can bring questions of racism, homophobia, classism, sexism, and so forth into the classroom through examining media and popular culture that students are seeing, hearing, and using every day. In addition, critical media literacy pedagogy is based on Freirian notions of praxis that link theory with action, especially as students create their own media representations for audiences beyond the classroom walls. Marc Prensky (2010) asserts:

Even elementary school students can change the world through online writing, supporting and publicizing online causes, making informational and public service videos and machinima, and creating original campaigns of their own design. Anything students create that 'goes viral' on the Web reaches millions of people, and students should be continually striving to make this happen, with output that both does good and supports their learning. (p. 66)

To accomplish this, teachers need to move beyond the traditional notion of critical media literacy as a primarily consumptive process toward a more productive pedagogy.

\section{Pushing Beyond Traditional Media Literacy}

In recent years, we have seen a shift from using technology as tools to convey individual ideas and expressions to the leveraging of individual strengths through technology to create community involvement (Jenkins, Clinton, Purushotma, Robison, \& Weigel, 2006). Jenkins and his colleagues (2006) describe this community involvement as participatory culture, explaining, "Participatory culture is emerging as the culture absorbs and responds to the explosion of new media technologies that make it possible for average consumers to archive, annotate, appropriate, and recirculate media content in powerful new ways" (p. 8). Yet, possibility and reality are often two different things. While large populations of students enter classrooms with years of experience using digital tools, their digital fluency does not mean they know how to capture the potential power of participatory culture (Campbell, 2005). These students "need to learn to manipulate their multimedia languages well, with conceptual and critical acumen" (p. 36).

The ideas presented by Jenkins and his colleagues (2006) agree with Campbell. They note research that suggests that participatory culture can increase peer learning, shift attitudes about intellectual property, diversify cultural expression, 
develop workplace skills, and empower conceptions of citizenship. They argue that accessing participatory culture becomes a part of the hidden curriculum and that students who are not fluent in this type of culture will be less successful in life after high school. "We are moving away from a world in which some produce and many consume media, toward one in which everyone has a more active stake in the culture that is produced" (Jenkins et al., 2006, p. 10).

Campbell finds the idea of leveraging information technologies a provocative potential in education, particularly in terms of production. Citing Jerome Bruner's The Culture of Education (1996), Campbell (2006) wonders if Bruner is suggesting that "one function of education is to give learners the symbolic systems they need to have recourse to more powerful symbolic systems" (p. 29). With carefully structured pedagogical guidance, Campbell believes educators can create a "metalinguistic" awareness that crosses boundaries previously constructed by genres, media, and intellectual disciplines. "For the first time, learners may 'write' not just with words or the illustrations common to one discipline but with an entire range of symbolic representations" (p. 29).

Our vision of the classroom coincides with that of Campbell. By embracing a critical media literacy pedagogy that emphasizes production rather than consumption, educators can equip students with the mindset needed to help shape their culture. Approaches such as the one we described in the opening of this article are important, but we cannot stop there. As De Zengotita (2002) points out, the issue is not whether or not we can differentiate between reality and the messages we receive on a daily basis, but whether or not we actually do it. His response to this question? "Of course not" (p. 35). This lack of differentiation between fiction and reality causes great concern. Cultural anthropologist Michael Wesch focuses much of his work on examining the potential, as well as pitfalls of technology, in the classroom. In an address to Higher Education Internet Technology Executives, Wesch (2007) sets forth two possible scenarios. In the first, he describes a world where society sees schools as increasingly irrelevant in their focus on information, equipping only the elite few with the means and creativity to control and produce content. He asserts that rather than watching the program, society itself becomes the program.

By taking control of the production of media texts, a productive stance within critical media literacy allows educators to distribute the means and creativity for controlling and producing content beyond a traditional information elite. Particularly, in an increasingly complex digital ecology, the ability to write not simply via print-based text but via multimodal and programmable mediums are an integral part 
of challenging power structures that manifest through media distribution. In his 2010 book, Program or be Programmed: Ten Commands for a Digital Age, Rushkoff writes:

Digital technology is programmed. This makes it biased toward those with the capacity to write the code. In a digital age, we must learn how to make the software, or risk becoming the software. It is not too difficult or too late to learn the code behind the things we use-or at least to understand that there is code behind their interfaces. Otherwise, we are at the mercy of those who do the programming, the people paying them, or even the technology itself. (p. 128)

By approaching critical media literacy through a productive, rather than simply a consumptive, lens, educators can help shape society toward the second scenario outlined by Wesch (2007), where schools "encourage kids to use media and technology and not let it use them." In this world, every member of society views reading and writing as socially connected. In this world, there is a culture of vigilance toward digital security and privacy. In this world, "you, like billions of others, are not a program. You, like billions of others, are the programmer." In Wesch's vision, the role of youth as producers is innately tied to how they contribute to and shape the democratic society they are a part of. The critical production of this model hinges on the production choices students make in offering social change.

\section{Implementing Critical Media Literacy in the Classroom}

We frame a pedagogy of critical media literacy within the critical literacy traditions established by theorists such as Freire and Macedo (1987), Giroux (2001), and Gramsci (1971). As such, the notion of literacy is not framed solely within formative and career-related skills of production and interpretation. Instead, we encourage educators and teacher educators to build

a more profound understanding of how the wider conditions of the state and society produce, negotiate, transform, and bear down on the conditions of teaching so as to either enable or disable teachers from acting in a critical and transformative way. (Giroux, 1987, pp. 14-15) 
This reflective process of looking at the ecology of schooling helps frame the kinds of activities and lessons we have developed through teaching a teacher education course on critical media literacy.

\section{UCLA's TEP Class on Critical Media Literacy}

In the Teacher Education Program at UCLA, we have been offering master's level classes in critical media literacy for several years, and in 2010 we incorporated the three-unit course, Ed466 Critical Media Literacy, into the course requirements for all new teacher candidates. This graduate level course prepares educators for teaching $\mathrm{K} 12$ students to explore their relationships with media, technology, and popular culture by critically questioning different types of representations and creating their own alternative media messages. All students analyze as well as create media projects related to their teaching.

Through various assignments such as creating wanted posters that require images combined with words, alternative book reports using multimedia, social media for addressing problematic representations, photographs, podcasts, word clouds, and digital stories, the students authentically demonstrate their competence with digital media as well as their understandings of the politics of representation. The assignments are structured to integrate technology-related tools into the educational experience through a critical pedagogical framework that encourages candidates to assess the authenticity, reliability, relevance, and bias of the messages as well as the different medium. The assignments are also productive as they require students to not only analyze and become better readers, but also to produce with these new tools and become 21st century writers.

We combine various literacy skills with the intention of expanding our students' understanding of literacy beyond the limitations of print-based concepts. We encourage students to recognize that literacy today means reading and writing photographs, music, movies, advertising, popular culture and also printed books and magazines. This expansive view of literacy is combined with a deeper understanding of literacy that explores the always-present connections of information and power. In addition, an expansive view of literacy is often the most motivating as students learn how to incorporate photography, music, social media, computers, and other technologies into their teaching. This is the easiest aspect of literacy instruction to implement and often the most fun for students. However, the more critical empowering aspects of the class are the engagement of ideology and power in the literacy process while creating alternative media. This deeper analysis and use of literacy emphasizes the essential role that literacy can play in social justice education. 
One assignment, the Wanted Poster, is an opportunity for new teachers to learn basic computer skills for combining images with words and visual design. The assignment also provides the space for student teachers to create posters to use as examples for their own students to see digital alternatives for demonstrating learning and reframing the discourse about whose story is seen and heard in the classroom. In one student project, a Social Studies student teacher created a wanted poster of Gabriela Silang, an indigenous woman in the Philippines who led her people in armed resistance against colonial domination. The text reads: "Wanted: Gabriela Silang; Description: First Filipinia to lead insurgent groups against the Spanish during the Philippine Revolution; Warning: She is armed and dangerous. Watch your back. She will swing at you with her bolo." When teachers and students create the opportunity to produce their own representations, they enact the power to determine whose stories are told and how.

Once teachers and students begin to recognize the power behind representation of others, we ask them to turn to themselves. In another activity, students use Voicethread.com to create their Through Other's Eyes assignment that involves posting an image representing a visual portrayal of an aspect of their identity that they have seen maligned in the media. They post the image and comment about how this representation negatively presents an aspect of their identity. Voicethread provides the ability for all the students to see and hear each other's reflection as well as add their comments to their peer's posting. In addition to providing experience with more sophisticated technology than the simple manipulation of images and text in the Wanted Poster, this assignment requires them to move beyond representation of others and push back at the media messages that saturate the world around us. In doing so, students have critiqued the portrayal of body image, immigration, domestic violence, alcoholism, and religion, as well as the intersections of racism, sexism, and classism. These powerful critiques help students explore the influence of visual images and the deep connection that media can have to identity, especially when the representation is negative.

In Literacy: Reading the Word and the World (1987), Freire and Macedo write, "Reading the world always precedes reading the word, and reading the word implies continually reading the world" (p. 35). Many of the activities in our preservice teachers' classes situated youth engagement, dialogue, and pedagogical reflection within the lived experiences that each student brought to the classroom. As educators, a focal point for the lessons we developed was deliberative reflection on how ideologies stemmed from the cultural readings of the world we've developed. For instance, Shor (1987) describes how reading the context of sitting within schools leads his 
students to understand the uncomfortable chair of the classroom as "a symbol of oppression" (p. 160). Within our own classes at UCLA, crafting these discussions and concepts of unpacking cultural hegemony within a critical media classroom meant building upon familiar media products and practices. One activity from the Ed466 class begins with students peeling the shrink-wrap packaging off of a liquid yogurt smoothie to expose the sterile white plastic bottle. After discussions about advertising and consumerism, students work collaboratively to transform the white bottle back into a sellable advertisement for different target audiences. The activity provides an opportunity for students to rethink product packaging and create target advertising that exposes the codes and conventions of advertising as it uses the languages of popular culture and marketing. Looking at the advertising in this activity helps illustrate that critical media literacy does not depend solely on the technology explosion of the last decade; it has always been important.

As the semester progresses, we continue to steep students in more sophisticated tools of media composition. To accomplish this, another activity takes students incrementally through the steps of creating a sound track with dialogue, narration, and sound effects to ultimately produce their own podcast that retells a classic nursery rhyme in one of many radio show genres such as a call-in talk show, sporting event, traffic report, weather forecast, or breaking news report. Later students combine these audio skills with the photography and visual literacy experiences when creating their multimedia alternative media projects. These final projects have been varied using different media and critiquing different topics such as a movie analyzing children's media, a documentary redoing the classic black \& white doll experiment with kindergarten students, spoof magazine ads of iMac eWaste, and Prezis, Pinterest boards, and original songs critiquing sexist representations of women in the media.

It is important to note, however, that while we continued to introduce more sophisticated media composition tools, we also did not want our students to lose sight of the real purpose of the course, creating sophisticated authors of critical media literacy texts. Thus, we continued to mix traditional media with more contemporary genres. In a group project turned in near the end of the quarter a group of students remixed a recent issue of People magazine. The cover, preserved, was augmented only with a small sticker announcing: "Do not open without your social justice shades!" Throughout the magazine, nearly every page is remixed to critique the messages of the popular culture publication. For instance, the infographic in the original magazine, "Names he calls your boobs" is amended with the subhead, "So that you are dehumanized, objectified, and sexualized." The lo-fi approach to media production illustrates that writing, criticizing, and fomenting critical consciousness 
via a pedagogy of critical media literacy is not contingent upon the flashy digital tools available in the 21st century classroom. Instead, still building on the ethos of participatory culture, these students challenge culture hegemonic dominance through cutting and pasting text to build new critical narratives. By matching their own font to an article called "Sex Quiz: Find Your Pleasure Spot's Personality" that features a woman posed in revealing underwear, the students create an entirely new media product. Stating that, "this magazine is trying to turn your sexuality into something that only encompasses sexual and visceral pleasure, rather than understanding the deeper meaning of who you are," the newly transformed text elevates the popular culture magazine into an instructive tool that layers dominant and counternarrative on top of each other. The dialogue between problematic images of representation and sexualization next to the nuanced critique create a playful guide for critical media literacy pedagogy. Likewise a similarly constructed page functions as a how-to guide for informing viewers "How to Critically Analyze This Ad About Sex Toys."

\section{Implications of Critical Media Literacy in the Classroom}

It is important for us to be transparent that throughout the class some of the activities students completed and turned in did not articulate critical perspectives. Some students, for instance, created wanted posters that just described a math formula, some created nursery rhyme podcasts that were just funny, and some incorporated commercial media and marketing genres that they see frequently performed in advertisements and television shows. In redesigning the marketing and title for a bottle of liquid yogurt, for instance, some students invoked the same stereotypes to attract their target audience that they had previously criticized. While these activities may be seen as shortcomings by some when teaching about critical media literacy, we see these as necessary building points within a classroom community. Educators can work within these transitional activities that build criticality to gauge the comfort level, proficiency, and amount of support students need in honing critical media literacy. Each activity that we developed in our class of preservice teachers (as within a K12 class) builds upon the content and ideas developed previously. While some students exhibited frustration, resistance, or hostility to components of this process, meeting students where they are and offering avenues for them to explore their own media assumptions is necessary. We recognize that this resistance we've encountered in classrooms is an important and under-researched aspect of critical media literacy pedagogy. Giroux (1987) writes,

It is important to stress that a critical pedagogy of literacy and voice must be attentive to the contradictory nature of student experience and voice 
and therefore establish the grounds whereby such experience can be interrogated and analyzed with respect to both their strengths and weaknesses. (p. 20)

As we continued to explore messaging, ideology, and hegemony over a semester, the work students completed built toward understandings of the politics of representation that underlie every media product students encounter. These new teachers were also building an awareness of hegemonic ideology that informs their pedagogical framework of inquiry and production, which will hopefully influence their future teaching.

For us, this notion of a pedagogy that builds on theory and real-world experiences of our students is a crucial component for thinking about how to incorporate critical media literacy into any content area or grade. A 21st century critical media literacy pedagogy is one that integrates discussions of media representation, power, and ideology into a class instead of teaching this content as something separate. Critical media literacy is not educational technology nor is it a collection of interesting lesson plans. Rather, critical media literacy is a pedagogy that should serve as a framework to guide teachers and students to understand the language and ideas of a discipline. Critical media literacy informs individuals and groups about how they encounter concepts in a history book, interpret a science experiment, or perceive an advertisement at a bus stop. The iterative process of looking at media and developing a personal, critical lens guides youth interpretations and ideologies over time.

We also see this pedagogy of critical media literacy as one that stands in contrast to how others are writing about media literacy more broadly. While participatory media is encouraging educators to more fully acknowledge and incorporate skills related to the manipulation of and exploration with digital tools, texts and articles focused on these skills do not acknowledge the necessity for critical investigation of how media is entrenched within existing politics of representation. We see claims of politically neutral pedagogies of media literacy as dangerous for today's connected youth. Such practices of adopting media literacy practices as noncritical tools reinforce Freire's (1970) banking model of education. Within this context, a media literacy pedagogy that is not critical-that does not confront and challenge the cultural hegemony that underlies the media products and tools created-is one that "attempts to control thinking and action, leads men and women to adjust to the world, and inhibits their creative power" (p. 77). 
Approaching critical media literacy from a productive stance allows youth to harness their creative powers to help shape society. Yet, we cannot expect them to begin forming a new world from scratch. Rather, it is important that students study the media forces that are currently influencing their culture. Wesch (2013) describes the power of re-creating a media product versus simply looking at it. In his explanation, he points his audience to the World Economic Forum site at weforum.org. The purpose of this forum, according to the site's authors, is to serve as "an independent international organization committed to improving the state of the world by engaging business, political, academic and other leaders of society to shape global, regional and industry agendas." The addition of a dash to the url will take viewers to the site we-forum.org, which at first glance seems almost identical. This site, however, was not created by the World Economic Forum. Rather, using the original site as a mentor text, the second site's authors, the Yes Men (Bichlbaum, 2010), studied each aspect of the site in an effort to create a plausible site that presented a slightly different perspective. By studying one influential site, students begin to see how to shape their own messages. The depiction here of media production as a challenging and responsive counternarrative illuminates the possibilities of what Leah Lievrouw (2011) documents as "culture jamming." Lievrouw writes, "Culture jamming captures and subverts the images and ideas of mainstream media culture to make a critical point..." (p. 73). Culture jamming as seen in Adbusters' spoofs (https://www. adbusters.org/), The Yes Men hoaxes (http://theyesmen.org/), and Banksy's graffiti art (http://www.banksy.co.uk/), often use humor, irony, satire, and parody to make their point more appealing to the public at large. While some culture jamming has involved illegal activities, we do not promote breaking any laws. We bring these ideas into the classroom for educators to consider the pedagogical potential that this type of media production can provide. When humor overlaps social commentary, students can take advantage of the power of parody and satire to challenge hegemonic stereotypes about race, class, gender, or any identity marker. The way humor can be used as a powerful tool for exposing ideology is something we analyze when looking at episodes of The Daily Show and The Colbert Report. Integrating culture jamming into the curriculum provides the potential to access higher order thinking skills, challenge dominant myths, make lessons more engaging, and allow students to create media products of social significance that can be shared beyond the classroom. This critical use of humor is also part of youth culture as seen in popular media such as The Simpsons TV show, Tobuscus Literal Trailers, and online memes. Not only can humor be pedagogical and critical, but through bringing academic uses of humor into K12 classrooms, affective filters lower, engagement increases, and learning becomes fun. 


\section{Conclusion: The Possibilities and Challenges Ahead}

As the possibilities afforded for learning engagement expand with recent advances in digital technology, so to do the challenges that lay ahead for critical media literacy educators. Returning to the teacher in the opening anecdote, shifts in technology mean it is no longer enough to simply analyze and explore the media products that youth frequently consume in school settings. The possibilities for media creation function as a mandate for what Morrell (2008) calls "critical textual production" (p. 115).

Critical media literacy, as we continue to state, is not constituted by ancillary activities within classrooms. It is to work toward a seamless praxis; the pedagogy of critical media literacy recognizes the multifaceted aspects of life and power in the 21st century. As Giroux notes (1987), "school life is not conceptualized as a unitary, monolithic, and ironclad system of rules and regulations, but as a cultural terrain characterized by the production of experiences and subjectivities amidst varying degrees of accommodation, contestation, and resistance" (p. 17). The advanced placement teacher in the introduction, like all critical media literacy educators, needs to continue to provoke and challenge critical consumption and production long after her students have finished collecting and analyzing media products related to unspun.

Ultimately, the pedagogy of critical media literacy for which we are advocating is crucial for identifying liberatory pathways toward democratic citizenship in the digital age. Students must be able to respond to, infer varied meanings of, and develop their own media in dialogue with dominant media messages; these are dispositions of civic participation with digital tools. The possibilities of a critical media literacy pedagogy in the age of participatory media are unbounded. In spite of the current political attacks on education and teachers, critical media literacy offers the tools and framework to help students become subjects in the process of deconstructing injustices, expressing their own voices, and struggling together to create a better society. 


\section{References}

Adorno, T., \& Horkheimer, M. (1944). The culture industry: Enlightenment as mass deception, dialectic of enlightenment. New York: Continuum. (Originally published as Dialektik der Aufklarung).

Bichlbaum, A. (2010). Scurrilous videos besmirch, enrage forum, leaders, world. The Yes Men. Retrieved from http://theyesmen.org/wef

Bruner, J. (1996). The culture of education. Cambridge, MA: Harvard University Press.

Buckingham, D. (2003). Media education: Literacy, learning and contemporary culture. Cambridge, MA: Polity Press.

Campbell, G. (2005). Podcasting in education. Educause Review, November/December, 33-44.

Campbell, G. (2006). Education, information technologies, and the augmentation of human intellect. Change: The Magazine of Higher Learning, 38(5), 26-31.

De Zengotita, T. (2002, April). The numbing of the American mind. Harpers Magazine.

Durham M.G., \& Kellner, D. (Eds.). (2005). Media and cultural studies: Keyworks (2nd ed.). Malden, MA: Blackwell.

Freire, P. (1970). Pedagogy of the oppressed. New York: Seabury Press.

Freire, P., \& Macedo, D. (1987). Literacy: Reading the word and the world. Westport, CT: Bergin \& Garvey.

Giroux, H. (1987). Introduction: Literacy and the pedagogy of political empowerment. In P. Freire \& D. Macedo (Eds.), Literacy: Reading the word and the world (pp. 1-28). London: Routledge.

Giroux, H. (2001). Theory and resistance in education. Westport, CT: Bergin \& Garvey.

Gramsci, A. (1971). Selections from the prison notebooks. London: Lawrence and Wishart.

Hobbs, R. (2011). Digital and media literacy: Connecting culture and classroom. Thousand Oaks, CA: Corwin.
Jackson, B., \& Jamieson, K. H. (2007). unSpun: Finding facts in a world of disinformation. New York: Random House.

Jenkins, H., Clinton, K., Purushotma, R., Robison, A. J., \& Weigel, M. (2006). Confronting the challenges of participatory culture: Media education for the 21st century. MacArthur Foundation.

Kellner, D. (1995). Media culture: Cultural studies, identity and politics between the modern and the postmodern. London: Routledge.

Kellner, D., \& Share, J. (2007). Critical media literacy, democracy, and the reconstruction of education. In D. Macedo \& S. R. Steinberg (Eds.), Media literacy: A reader (pp. 3-23). New York: Peter Lang Publishing.

Lievrouw, L.A. (2011). Alternative and activist new media. Cambridge, MA: Polity Press.

Masterman, L. (2001). Teaching the media. New York: Routledge.

Media literacy defined: National Association for Media Literacy Education. (2013). National Association for Media Literacy Education. Retrieved from http://namle.net/ publications/media-literacy-definitions/

Morrell, E. (2008). Critical literacy and urban youth: Pedagogies of access, dissent, and liberation. New York: Routledge.

Prensky, M. (2010). Teaching digital natives: Partnering for real learning. Thousand Oaks, CA: Corwin.

Rushkoff, D. (2010). Program or be programmed: Ten commands for a digital age. New York: OR Books.

Scheibe, C., \& Rogow, F. (2012). The teacher's guide to media literacy: Critical thinking in a multimedia world. Thousand Oaks, CA: Corwin.

Shor, I. (1987). Critical teaching \& everyday life. Chicago: University of Chicago Press.

Thoman, E., \& Jolls, T. (2005). Five questions that can change the world. San Francisco: Center for Media Literacy. 
Wesch, M. (2007). Human futures for technology and education. Teaching and Learning with Technology Conference.

Wesch, M. (2013). The end of wonder in the age of whatever. Teaching and Learning Symposium, Illinois State University, Normal, IL.
Zinn, H. (2002). You can't be neutral on a moving train: A personal history of our times. Boston: Beacon Press.

Zinn, H., Ellis, D., Mueller, D., Damon, M., \& First Run/lcarus Films. (2004). Howard Zinn: You can't be neutral on a moving train: A documentary. Brooklyn, N.Y: First Run/ Icarus Films.

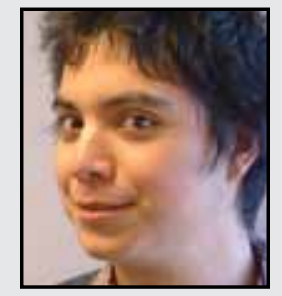

Antero Garcia is an Assistant Professor in the English department at Colorado State University in Fort Collins, CO. Antero's research focuses on developing critical literacies and civic identity through the use of mobile media and game play in formal learning environments. Prior to moving to Colorado, Antero was a teacher at a public high school in South Central Los Angeles for seven years. Antero received his $\mathrm{PhD}$ in the Urban Schooling division of the Graduate School of Education and Information Studies at the University of California, Los Angeles.

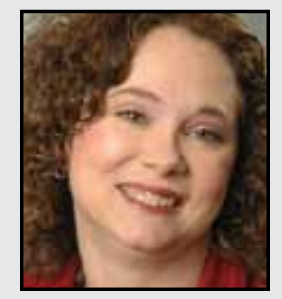

Robyn Seglem is an assistant professor in content literacy at Illinois State University. She has served as a co-director of the Flint Hills Writing Project, an affiliate with the National Writing Project, and is a nationally board certified teacher. She taught for nine years in the middle school and high school language arts classroom. Her research focuses on literacy and technology, adolescent literacy, and content area literacy. Dr. Seglem's work has appeared in publications in venues such as The Journal of Adolescent and Adult Literacy, English Journal, Voices from the Middle, and The Journal of Language and Literacy Education. 


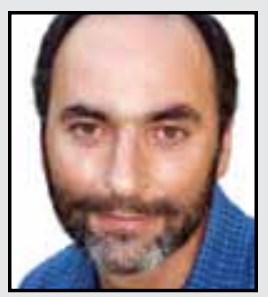

Jeff Share is a Faculty Advisor in the Teacher Education Program at the University of California, Los Angeles (UCLA). He works with new teachers in a master's level credentialing program at UCLA and also provides professional development training in critical media literacy with teachers in the Los Angeles Unified School District. His research focuses on theoretical frameworks and practical applications for teaching critical media literacy in inner-city classrooms. Share is the author of, "Media Literacy is Elementary: Teaching Youth to Critically Read and Create Media" (2009), Peter Lang Publishers.

\section{LINK TO:}

http://www.theamericancrawl.com 